УДК $541.49: 546.65: 546.175$

(C) 2015

Дрючко О. Г., кандидат хімічних наук,

Стороженко Д. О., кандидат хімічних наук,

Бунякіна Н. В., кандидат хімічних наук,

Іваницька І. О., кандидат хімічних наук,

Голубятніков Д. В., студент,

Китайгора К. О., студентка

Полтавський національний технічний університет імені Юрія Кондратюка

\title{
ПЕРЕТВОРЕННЯ У СИСТЕМАХ НІТРАТНИХ ПРЕКУРСОРІВ НА ПІДГОТОВЧИХ СТАДІЯХ ФОРМУВАННЯ РЗЕ-ВМІСНИХ ОКСИДНИХ ФУНКЦІОНАЛЬНИХ МАТЕРІАЛІВ
}

\section{Рецензент - кандидат фізико-математичних наук А. Т. Лобурець}

\begin{abstract}
Із застосуванням комплексу фізико-хімічних методів авторами вивчено природу й особливості хімічної взаємодії, теплових перетворень $\left(25-1000^{\circ} \mathrm{C}\right)$ структурних компонентів у системі нітратів неодиму $i$ калію, як модельних систем нітратів рідкісноземельних елементів і елементів IА групи періодичної системи, амонію, щуо нині широко використовуються у синтезах, технологічних регламентах створення на їх основі функціональних матеріалів різного призначення із заданим комплексом структурно-чутливих характеристик. Виявлена низка особливостей $i$ закономірностей у їх сукупній поведіниі.
\end{abstract}

Ключові слова: неодим, калій, нітрати, комплексоутворення, координаційні сполуки, термічні перетворення, властивості.

Постановка проблеми. Значна увага, що нині приділяється вивченню нанорозмірних матеріалів, обумовлена, насамперед, істотними відмінностями їх властивостей від властивостей об'ємних матеріалів аналогічного складу та є результатом виявлення ними кванторозмірних ефектів.

Для одержання нанодисперсних неорганічних матеріалів на основі оксидів перехідних і рідкісноземельних елементів найбільш перспективними $\epsilon$ використання методів «м'якої хімії», основаних на проведенні синтезу із водних чи неводних розчинів за відносно невисоких температур. Їх ключовими перевагами являються можливість одержання продуктів із контрольованим складом i мікроморфологією, економічність, екологічність та інші. На жаль, переважна більшість відомих на сьогоднішній день досліджень не дає можливості сформулювати загальні принципи створення наноматеріалів, що мають заданий склад, мікро- і мезоструктуру, функціональні характеристики. Основною причиною цього є те, що механізм формування наночастинок у вказаних умовах $\epsilon$ достатньо складним 3 фізико- хімічної точки зору і може включати паралельно протікаючі процеси гідратації (сольватації), асоціації, комплексоутворення, утворення і трансформування гетерофаз, закономірності перебігу яких мало вивчені. У зв'язку з цим, однією з головних задач, які виникають під час розробки відтворюваних методів направленого синтезу нанодисперсних матеріалів із використанням підходів «м'якої хімії», являється детальне вивчення механізмів і динаміки процесів, протікаючих під час формування наночастинок. Таке фундаментальне вивчення передбачає системне дослідження складу та мікроморфології проміжних сполук, які у більшості випадків визначають мікроструктуру і структурно-чутливі характеристики кінцевих функціональних наноматеріалів.

Сучасні оксидні РЗЕ-вмісні функціональні матеріали надзвичайно різноманітні. Загальним об'єднуючим моментом для них усіх виступає будова. Перехідні метали у структурі складних оксидів координують кисневі поліедри різної конфігурації. Сама структура речовин формується шляхом різного сполучення поліедрів між собою, які в різних комбінаціях можуть об'єднуватися вершинами, ребрами, гранями. У пустотах, утворених фрагментами рядів поліедрів, розмішуються більші за розміром катіони лужних, лужноземельних, рідкісноземельних елементів. Багато властивостей складних оксидів залежать не тільки від їх складу і структури, а і від дефектної структури, що дає змогу цілеспрямовано впливати на їх цільові параметри. Способи використання вказаних функціональних матеріалів можуть бути різними: кераміка, монокристали, тонкі плівки, товстоплівкові покриття, що виявляють проміжні властивості між власне плівками і об'ємними утвореннями.

Виявлення у оксидних РЗЕ-вмісних сполуках зі структурою граната, перовскіта наборів унікаль- 


\section{TEХНІЧНІ НАУКИ}

них властивостей (орієнтаційних фазових переходів, доменної структури, оптичної активності, величезної магнітної анізотропії і магнітострикції, вдале поєднання оптичних, теплофізичних i механічних властивостей) відкриває широкі перспективи їх практичного використання. Вони мають складну структуру і у технологічному відношенні являють собою непрості об'єкти, що інтенсивно досліджуються. Нині сформульовані загальні принципи відносно розподілу катіонів за кристалографічними місцями їх структури та виявлені великі можливості ізоморфних заміщень. Широта функціональних завдань, принципів і способів їх вирішення, відсутність матеріалів, що повністю задовольняють увесь комплекс технічних і технологічних вимог, їх сумісність зумовлюють відсутність універсальних методів їх розв'язку.

Аналіз основних досліджень і публікацій, у яких започатковано розв'язання проблеми. Нині продовжується пошук нових методів і комплексних технологій для синтезу спеціальних, функціональних оксидних РЗЕ-вмісних матеріалів із використанням рідких багатокомпонентних нітратних систем [2-25]. Такі технологічні схеми базуються на одержанні дрібнодисперсних порошкових матеріалів хімічною гомогенізацією вихідних компонентів під час спільного виділення продуктів із рідкої фази послідовним чи сумісним осадженням 3 наступним термообробленням у вигляді їх гідроксидів чи інших нерозчинних сполук, використанні методу термолізу розчинника, іонних і молекулярних координаційних прекурсорів, заміні розчинника, сушінні розпиленням, кріохімічній кристалізації, золь-гель процесах та інших. Синтез таких нанокристалічних матеріалів $\epsilon$ складною науковотехнологічною проблемою.

Дані дослідження нині направлені на покращання комплексу структурно-чутливих характеристик цільового продукту шляхом оптимізації умов синтезу, вивчення особливостей фрактальної структури, що утворюють наночастинки під час виділення з розчинів, процесів, протікаючих на краях зерен у полікристалічних системах, що визначаються особливостями хімічної взаємодії компонентів системи, нерівноважністю їх протікання; застосування методу «структурного дизайну» для керування електрофізичними властивостями; дослідження наноупорядкування у кристалічних системах; на розробку нових видів матеріалів (мультифероїків, метаматеріалів) та інше.

Найновітніші дані про результати подібних досліджень далеко нерівноцінні. У низці випадків вони зумовлені великими експерименталь- ними складнощами, часом носять суперечливий характер і не дають повного уявлення про комплексоутворюючу здатність рідкісноземельних елементів у подібних об'єктах. Однозначній інтерпретації перебігу вищевказаних процесів часто також заважає одночасне співіснування декількох метастабільних форм продуктів термолізу, залежність їх структури від передісторії самого процесу, аморфний чи погано закристалізований стан прекурсорів [10].

Авторами публікації [19] виявлено стимулюючу дію безперервного нагрівання на фазоутворення складних оксидів рідкісноземельних елементів під час твердофазного синтезу та встановлено, що ініціююча дія такого нагрівання тим ефективніша, чим менше розмір кристалітів вихідних компонентів.

Наявні відомості щодо стану і можливих напрямів удосконалення технологій створення оксидних РЗЕ-вмісних функціональних матеріалів, існуючі вимоги до їх стабільності та відтворюваності властивостей ініціювали проведення нашого дослідження.

Метою даної роботи є фундаментальні дослідження кооперативних процесів, протікаючих під час одержання оксидних РЗЕ-вмісних функціональних матеріалів 3 використанням нітратів елементів різної електронної структури, та знаходження можливих прийомів впливу на рідкофазні і твердофазні системи, основаних на термічній активації реагентів, з метою відтворення їх структурно-чутливих характеристик.

Постановка завдання $і$ методи вирішення. У роботі для оцінки можливості керування вказаними процесами і одержання матеріалів із заданими властивостями у якості модельної вивчена система $\mathrm{KNO}_{3}-\mathrm{Nd}\left(\mathrm{NO}_{3}\right)_{3}-\mathrm{H}_{2} \mathrm{O}$, компоненти якої задають технічні характеристики продукту синтезу або модифікують його фізичні властивості. Вибір для дослідження нітрату неодиму (представника рідкісноземельних елементів церієвої підгрупи) обумовлений існуючими статистичними даними про найбільшу вірогідність зміни складу чи структури сполук, утворюваних неодимом, у разі переходу по природному ряду від лантану до лютецію. Вибір значення температурного перерізу $50{ }^{\circ} \mathrm{C}$ для вивчення ізотерми розчинності системи обумовлений нестійкістю гексагідрата нітрату неодиму і початком плавлення його у кристалізаційній воді при $68{ }^{\circ} \mathrm{C}$, вище якої він перебуває у рідкому сильно в'язкому метастабільному стані.

Для вирішення поставленої задачі наші дослідження спрямовані на: 
- грунтовний аналітичний літературний огляд наявних наукових відомостей за тематикою роботи;

- вибір методів і засобів фізико-хімічного дослідження модельної системи;

- оволодіння методикою і технікою підготовки і проведення експерименту;

- експериментальне вивчення хімічної взаємодії компонентів, гетерогенних рівноваг у водно-сольовій системі $\mathrm{KNO}_{3}-\mathrm{Nd}\left(\mathrm{NO}_{3}\right)_{3}-\mathrm{H}_{2} \mathrm{O}$ $\left(50{ }^{\circ} \mathrm{C}\right)$ із застосуванням комплексу фізикохімічних методів;

- побудову ізотермічної діаграми розчинності системи. Визначення концентраційних меж кристалізації вихідних речовин і виявлених у системі комплексних солей;

- 3'ясування оптимальних умов росту і проведення синтезу координаційних нітратів неодиму і калію; вивчення їх властивостей та підтвердження індивідуальності;

- термографічні дослідження твердих фаз, що виділяються у системі нітратів неодиму і калію iз розчинів, розчинів-розплавів, розплавів;

- 3'ясування природи і особливостей послідовних термічних перетворень у РЗЕ-вмісних нітратних багатокомпонентних системах у різних агрегатних станах у ході їх термооброблення;

- використання одержаних знань для обгрунтування підготовчих процесів у виробництві РЗЕ-вмісних функціональних матеріалів різного призначення, розробки можливих способів керування ними.

Для 3'ясування характеру хімічної взаємодії i фазових рівноваг у водно-сольовій системі досліджуваних нітратів (прекурсорів багатокомпонентних оксидних функціональних матеріалів) у повних концентраційних співвідношеннях в температурному діапазоні існування розчинів використаний метод розчинності, описаний у працях Аносова та Горощенко $[1,6]$ і оснований на дослідженні вказаної властивості, як однієї з найбільш «чутливих» до виявлення фазових перетворень у системі, що являється одночасно параметром iï стану, і до того ж простими доступними нині експериментальними методами.

Метод дає змогу знайти межі саморозвитку, до яких прямує ізольована система заданого складу у конкретних умовах, у рівноважному стані.

Вивчення впливу технологічних змін умов синтезу на характеристики цільового продукту обгрунтовується на основі фундаментальних принципів безперервності, відповідності, сумісності у гетерогенних і гомогенних системах закону діючих мас, що моделюються.

3 метою підвищення достовірності одержуваних даних використане одночасне комплексне дослідження розчинності компонентів системи, густини і відносного показника заломлення світла її розчинів. I топологічним (взаємно однозначним, взаємно безперервним) відображенням існуючих у системі фаз і змін їх властивостей зі зміною параметрів стану буде зображення побудованої діаграми розчинності досліджуваної системи за певних з'ясованих умов.

Природу перетворень твердих фаз, що кристалізуються у досліджуваній потрійній системі, вивчали методами термічного аналізу за допомогою дериватографа Q - $1500 \mathrm{D}$, розробленого термоаналітичного комплексу, а також методами елементного та рентгенофазового аналізу.

Експериментальна частина. У роботі в якості вихідних солей використовували гідратовані і безводні нітрати вказаних елементів марки «ч.д.а.», додатково очищені перекристалізацією.

Гетерогенні рівноваги у водній системі солей нітратів вивчали ізотермічно при $50{ }^{\circ} \mathrm{C}$ у сухоповітряному термостаті, безперервно перемішуючи за допомогою пристрою багатопозиційного електромагнітного перемішування.

Рівновага фаз встановлювалася протягом 1-2 діб. Відбір проб рідких і твердих фаз досліджуваних сумішей $з$ метою попередження їх кристалізації і максимального відділення маточного розчину здійснювали спеціальними пробовідбірниками у тих же ізотермічних умовах за допомогою форвакуумного насосу.

Проводили хімічний аналіз рідких і твердих фаз, «залишків» на вміст іонів $\mathrm{Nd}^{3+}$, визначали трилонометрично; іонів $\mathrm{K}^{+}$- розрахунком за різницею, виходячи із загального вмісту нітратів у сухому залишку.

Одержані експериментальні дані з вивченої системи для окремих іонів перераховувались на сольовий вміст, узагальнювались, зводились у таблицю 1 і згідно 3 принципом відповідності наносились на діаграму розчинності (рис. 1).

Графічне відображення складу твердих фаз, що утворюються у системі, проводили за Скрейнемакерсом [1, 6]. Їх індивідуальність підтверджували хімічним, рентгенофазовим, термографічним та іншими методами аналізу.

Використаний метод розчинності являється експериментальним і базується на геометричній побудові рівноважної діаграми розчинності. 
TЕХНІЧНІ НАУКИ

\section{1. Дані з вивчення фазових рівноваг у системі $\mathrm{KNO}_{3}-\mathrm{Nd}\left(\mathrm{NO}_{3}\right)_{3}-\mathrm{H}_{2} \mathrm{O}$ nри $50^{\circ} \mathrm{C}$}

\begin{tabular}{|c|c|c|c|c|c|c|c|}
\hline \multirow{3}{*}{$\begin{array}{l}\text { Точки } \\
\text { складу }\end{array}$} & \multicolumn{4}{|c|}{ Насичений розчин } & \multirow{2}{*}{\multicolumn{2}{|c|}{$\begin{array}{c}\text { Склад «залишку», } \\
\text { мас. \% }\end{array}$}} & \multirow{3}{*}{$\begin{array}{l}\text { Тверді } \\
\text { фази }\end{array}$} \\
\hline & \multicolumn{2}{|c|}{ Склад, мас. \% } & \multicolumn{2}{|c|}{ Властивості } & & & \\
\hline & $\mathrm{KNO}_{3}$ & $\mathrm{Nd}\left(\mathrm{NO}_{3}\right)_{3}$ & $d \cdot 10^{3} \kappa 2 / \mathrm{m}^{3}$ & $n$ & $\mathrm{KNO}_{3}$ & $\mathrm{Nd}\left(\mathrm{NO}_{3}\right)_{3}$ & \\
\hline 1 & 2 & 3 & 4 & 5 & 6 & 7 & 8 \\
\hline $1 \mathrm{~A}$ & 44,88 & 0,00 & 1,223 & 1,3748 & 100,00 & 0,00 & A \\
\hline 2 & 40,12 & 8,67 & 1,391 & 1,3862 & 97,93 & 1,25 & Теж \\
\hline 3 & 35,21 & 20,31 & 1,514 & 1,4014 & 95,68 & 1,72 & $《-»$ \\
\hline 4 & 28,46 & 38,81 & 1,602 & 1,4406 & 94,51 & 3,22 & $\langle-»$ \\
\hline 5 & 26,80 & 48,65 & 1,858 & 1,4659 & 94,03 & 4,36 & $《-»$ \\
\hline 67 & & & & & 91,54 & 5,56 & $\langle-»$ \\
\hline 7 & & & & & 74,51 & 23,07 & $A+B$ \\
\hline $8 \mathrm{D}\}$ & 27,26 & 51,82 & 2,092 & 1,4781 & 37,95 & 52,73 & Теж \\
\hline $9 \int$ & & & & & 33,84 & 56,49 & $\mathrm{~B}$ \\
\hline 10 & 24,08 & 53,28 & 2,064 & 1,4764 & 34,07 & 57,16 & Теж \\
\hline 117 & & & & & 34,58 & 57,29 & $\langle-»$ \\
\hline $12 \mathrm{E}$ & 21,34 & 54,91 & 2,068 & 1,4791 & 31,95 & 60,97 & $\mathrm{~B}+\Gamma$ \\
\hline 13 & & & & & 29,82 & 65,46 & $\Gamma$ \\
\hline 14 J & 17,03 & 57,09 & 1,960 & 1,4772 & 30,12 & 66,91 & Теж \\
\hline 15 & 13,94 & 61,08 & 1,969 & 1,4778 & 29,23 & 66,65 & $\langle-»$ \\
\hline 167 & & & & & 29,61 & 67,07 & $\langle-»$ \\
\hline $17 \mathrm{~F}$ & 11,49 & 63,31 & 2,124 & 1,4822 & 15,17 & 70,18 & $\Gamma+Б$ \\
\hline 18 & & & & & 8,01 & 70,76 & Теж \\
\hline 19 J & 4,44 & 66,02 & 1,964 & 1,4726 & 1,76 & 72,49 & Б \\
\hline $20 \mathrm{C}$ & 0,00 & 66,16 & 1,974 & 1,4667 & 0,00 & 75,28 & $\langle-»$ \\
\hline
\end{tabular}

Примітка: *A - $\mathrm{KNO}_{3}$; Б - $\mathrm{Nd}\left(\mathrm{NO}_{3}\right)_{3} \cdot 6 \mathrm{H}_{2} 0 ; \mathrm{B}-\mathrm{K}_{2}\left[\mathrm{Nd}\left(\mathrm{NO}_{3}\right)_{5}\left(\mathrm{H}_{2} \mathrm{O}\right)_{2}\right] ; \Gamma-\mathrm{K}_{3}\left[\mathrm{Nd}_{2}\left(\mathrm{NO}_{3}\right)_{9}\right] \cdot \mathrm{H}_{2} \mathrm{O}$

Згідно з цим методом готують набір сумішей, склад яких відповідає низці точок на діаграмі розчинності, відповідно, з двох сторін вихідних компонентів, що містять надлишок їх кристалів. В ізотермічних умовах суміші приводять до стану рівноваги, момент якого контролюється за незмінністю складу їх рідких і твердих фаз. Фазові рівноваги сумішей досліджують у повних, $100 \%$ концентраційних співвідношеннях компонентів. По даним хімічного аналізу на діаграму складу наносять фігуративні точки насичених розчинів сумішей, а також відповідні їм склади твердих «залишків». Перші з'єднують безперервною кривою. Одержана крива являється ізотермою розчинності. Положення нонваріантних (перехідних, евтонічних) точок на ізотермі розчинності визначається по перетину віток розчинності досліджуваних сполук й уточнюється вивченням фазового складу осадів. Склад твердих фаз визначається способом графічної побудови (методом Скрейнемакерса) і хімічним аналізом після виділення їх у чистому вигляді.

Користуючись описаною методикою, можна будувати ізотерми розчинності будь-якого типу: евтонічного, систем 3 хімічними сполуками між компонентами і твердими розчинами.

Використаний метод дає змогу досліджувати водно-сольові системи комплексно й іншими способами: рідку фазу - рефракції, густини, питомої електропровідності, в'язкості; фазовий склад осадів - рентгенографії, мікроскопії, термографії та іншими. До переваг методу слід віднести можливість простими засобами визначити характер взаємодії між вихідними компонентами і вказати близький склад сполук, що утворюються, не виділяючи їх у чистому виді. До недоліків відносимо значну трудомісткість.

У роботі для спрощення побудови ізотермічної діаграми розчинності потрійної системи зображення складу здійснювалось у рівнобедреному прямокутному трикутнику Розебома [6]. Представлений вид діаграми $\epsilon$ найбільш простим i зручним для проведення розрахунків процесів випаровування розчинів і кристалізації під час охолодження у досліджуваних нами системах.

Вивчення взаємної поведінки структурних компонентів у рідкій фазі та фазових рівноваг у системі нітрат калію - нітрат неодиму - вода, побудова іiі ізотерми розчинності дають можливість визначити концентраційні межі виділення у 
тверду фазу калієвих координаційних нітратів неодиму. Одержані дані дали змогу здійснити вибір оптимальних умов виділення комплексних нітратів та провести їх синтез ізотермічно випаровуванням розчинника. За незначного ступеня пересичення маточного розчину були одержані ізометричні монокристали бінарних калієвих нітратів. Габітус кристалів $\mathrm{K}_{2}\left[\mathrm{Nd}\left(\mathrm{NO}_{3}\right)_{5}\left(\mathrm{H}_{2} \mathrm{O}\right)_{2}\right]$ (рис. 2a), $\mathrm{K}_{3}\left[\mathrm{Nd}_{2}\left(\mathrm{NO}_{3}\right)_{9}\right] \cdot \mathrm{H}_{2} \mathrm{O}$ (рис. 2б) визначається складом сполук, природою і вмістом складових катіонів, умовами кристалізації та являється їх діагностичною ознакою.

Хімічний аналіз синтезованих сполук підтверджує співвідношення мас елементів у запропонованих вище формулах.

Проведений рентгенофазовий аналіз зразків вказує, що сполуки характеризуються індивідуальним набором, положенням та інтенсивністю ліній на дифрактограмах (рис. 3) та підтверджує їх індивідуальність.

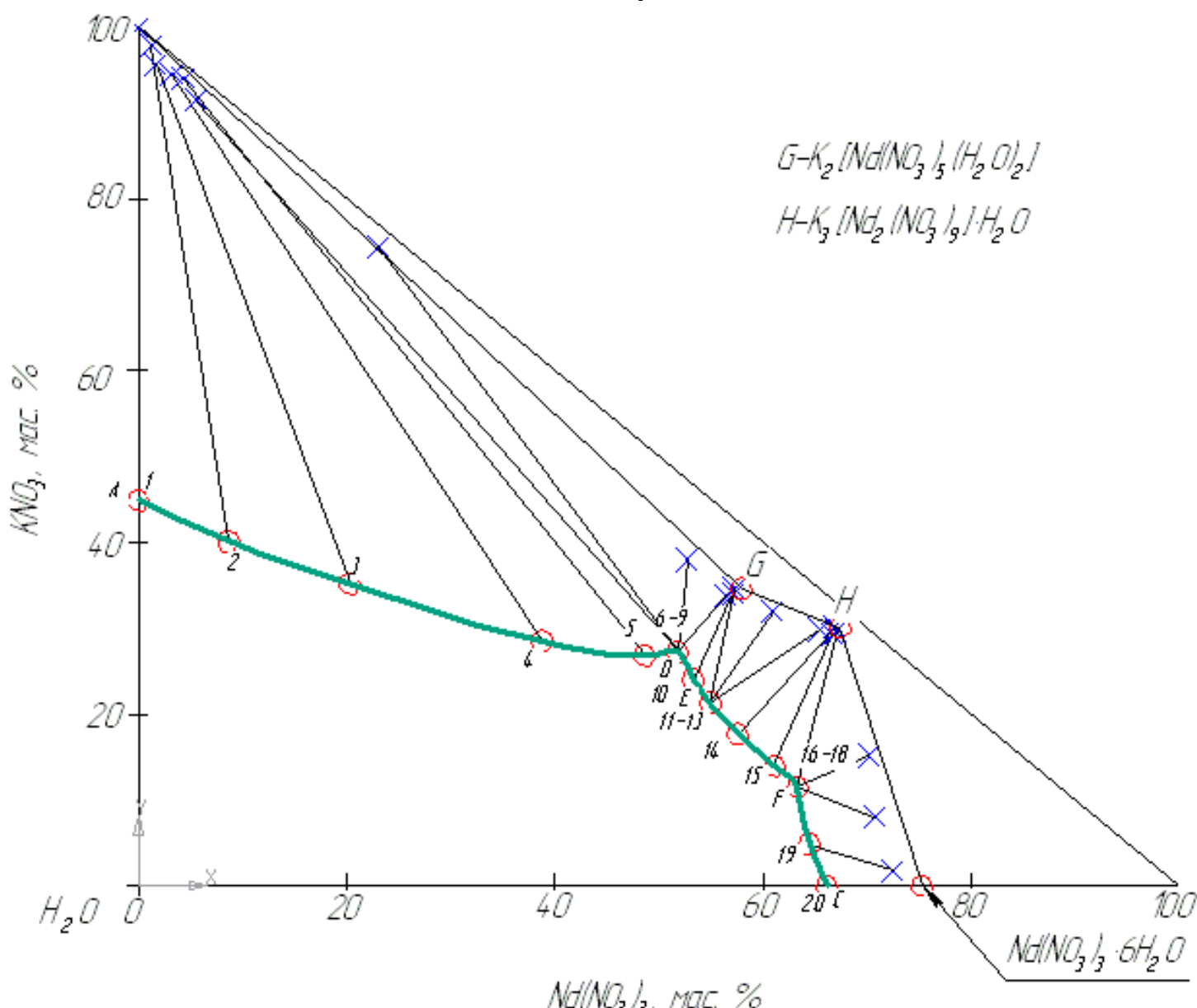

Рис. 1. Ізотерма розчинності системи $\mathrm{KNO}_{3}-\mathrm{Nd}\left(\mathrm{NO}_{3}\right)_{3}-\mathrm{H}_{2} \mathrm{O}$ при $50^{\circ} \mathrm{C}$
Термографічні дослідження вихідних нітратів $\mathrm{KNO}_{3}, \mathrm{Nd}\left(\mathrm{NO}_{3}\right)_{3} \cdot 6 \mathrm{H}_{2} \mathrm{O}$; твердих фаз, що утворюються у системі нітратів неодиму і калію; синтезованих калісвих координаційних нітратів РЗЕ проводили на розробленому термоаналітичному комплексі для диференціального термічного аналізу i дериватографі системи Ф. Паулік, Й. Паулік, Л. Ердей Q - 1500 D.

Розробка термоаналітичного комплексу зумовлена необхідністю детального дослідження i уточнення температурних меж протікання низки теплових процесів, що накладаються (дегідратації, розкладання), фазових перетворень (поліморфних, плавлення) в умовах і режимах, що апаратурно неможливо відтворити на дериватогpaфi.

Використані засоби дали змогу дослідити фізичні і хімічні перетворення в одержаних сполуках під впливом теплоти та підтвердити їх індивідуальність.
$\mathrm{N} /\left(\mathrm{NO}_{3}\right)_{3}, \mathrm{MaC} . \%$ 


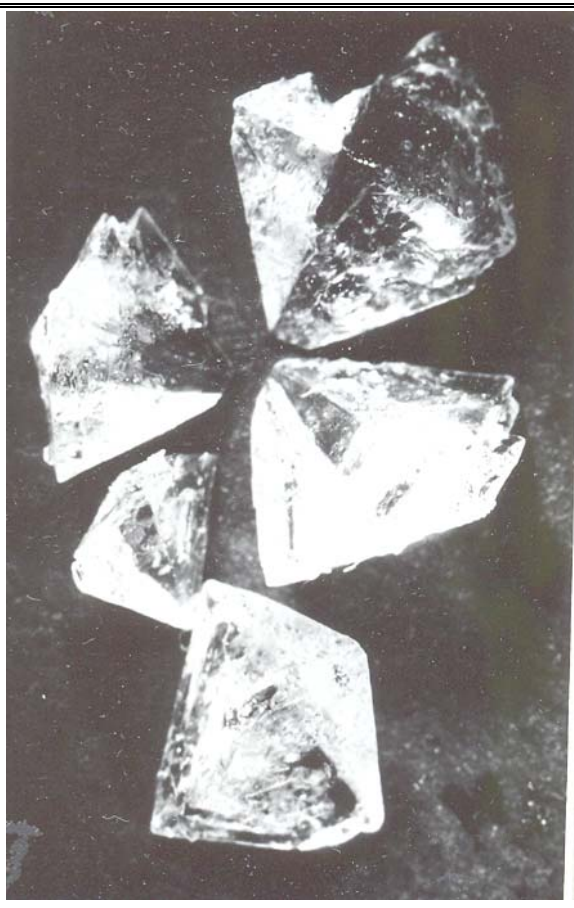

a)

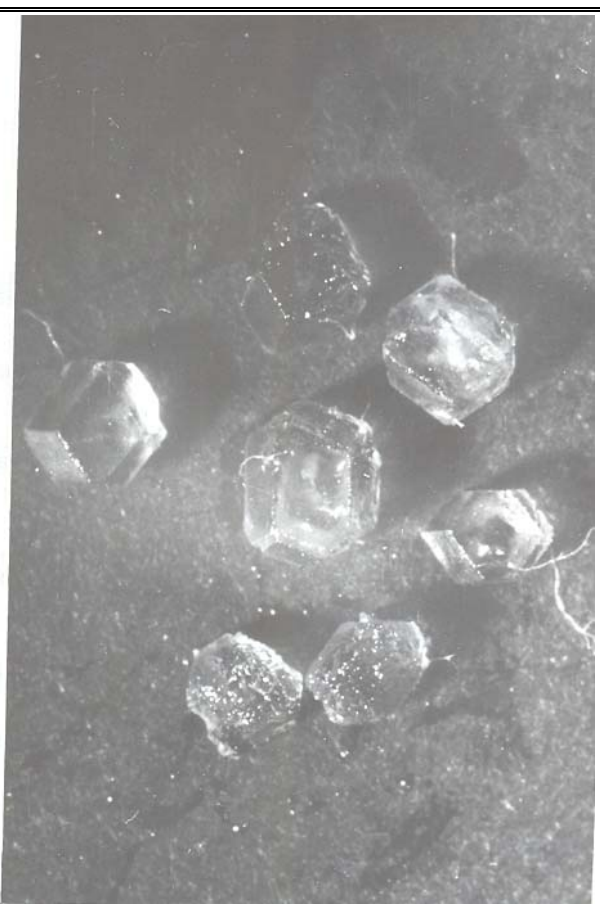

б)

Рис. 2. Мікрофотографії кристалів а) $\mathrm{K}_{2}\left[\mathrm{Nd}\left(\mathrm{NO}_{3}\right)_{5}\left(\mathrm{H}_{2} \mathrm{O}\right)_{2}\right]$; б) $\mathrm{K}_{3}\left[\mathrm{Nd}_{2}\left(\mathrm{NO}_{3}\right)_{9}\right] \cdot \mathrm{H}_{2} \mathrm{O}$

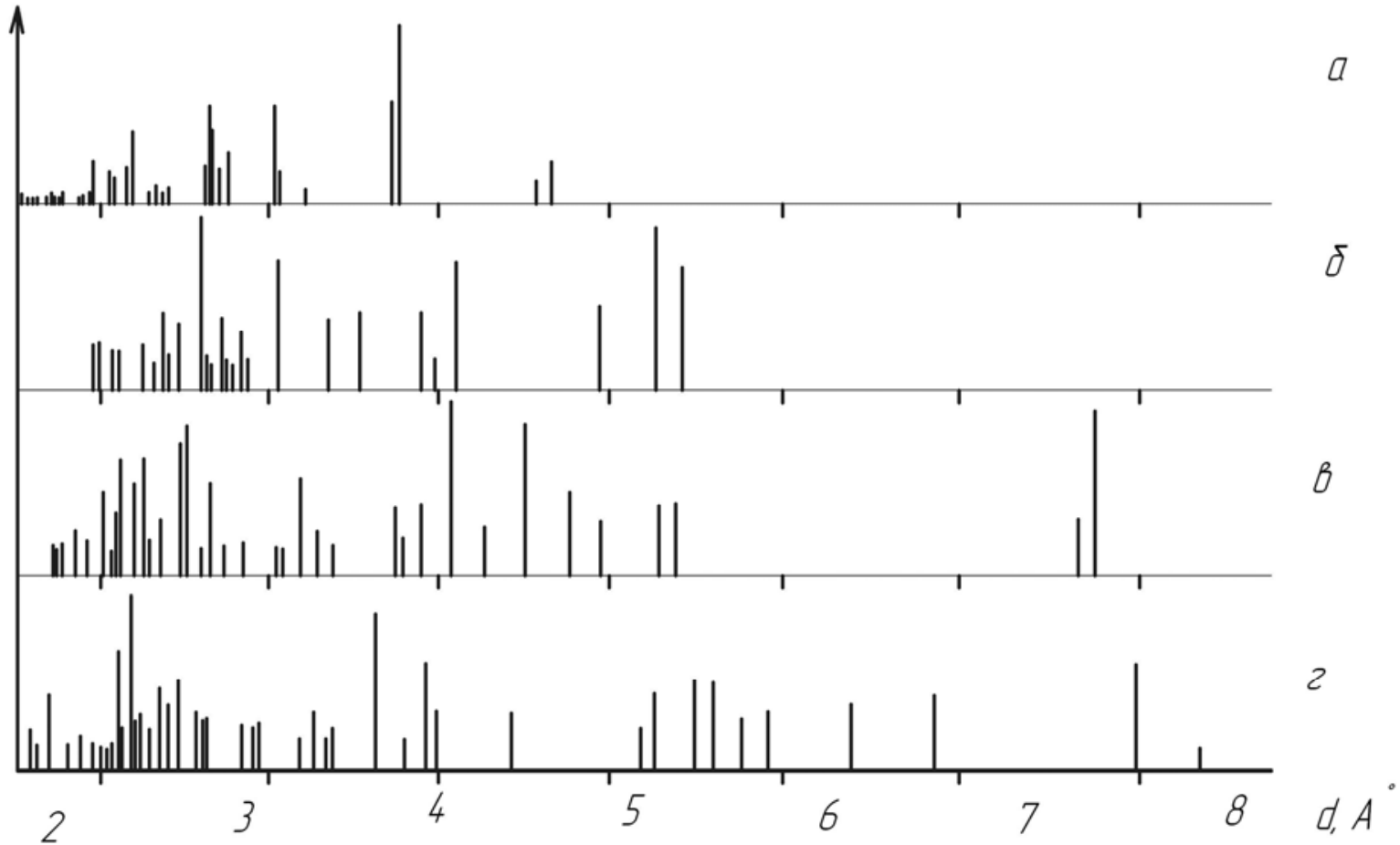

Рис. 3. Штрихрентгенограми вихідних солей нітратів:

а) калію, г) неодиму і виявлених координаційних сполук б) $\mathrm{K}_{2}\left[\mathrm{Nd}\left(\mathrm{NO}_{3}\right)_{5}\left(\mathrm{H}_{2} \mathrm{O}\right)_{2}\right]$; в) $\mathrm{K}_{3}\left[\mathrm{Nd}_{2}\left(\mathrm{NO}_{3}\right)_{9}\right] \cdot \mathrm{H}_{2} \mathrm{O}$

Результати досліджень. Для вирішення поставленої задачі у роботі проаналізовано дані, одержані власними експериментальними дослід- женнями і знайдені в результаті пошуку із наукових вітчизняних і зарубіжних джерел. На їх основі проводиться інтерпретація встановлених 


\section{TEХНІЧНІ НАУКИ}

термічних фізико-хімічних перетворень у модельній системі нітратів неодиму (представника лантаноїдів церієвої підгрупи) і калію (представника елементів IA групи періодичної системи).

Фізико-хімічними методами у водно-сольовій системі нітратів неодиму і калію при $50{ }^{\circ} \mathrm{C}$ між структурними компонентами встановлені обмінні взаємодії з утворенням 2-х нових аніонних координаційних сполук. Нами були вивчені кількість, склад, концентраційні межі кристалізації фаз, що співіснують у системі, характер їх розчинності, побудована фазова діаграми розчинності. Концентраційним межам насичених розчинів, із яких виділяються комплексні нітрати, відповідають склади нонваріантних точок ізотерми розчинності. Встановлені можливі види сполук. Всі вони синтезовані у монокристалічному вигляді. Проведено системне вивчення низки їх властивостей.

Одержана ізотермічна діаграма розчинності системи у температурному діапазоні існування розчинів наочно ілюструє складність характеру взаємодії між структурними компонентами у досліджених об'єктах, стадійність перетворень та вказує на достатню чутливість та ефективність застосованого комплексу експериментальних методів для вирішення подібних завдань.

У вивчених водно-сольових системах зі збільшенням енергіï активації нагріванням посилюється комплексоутворююча здатність Ln. Конкуруючі процеси заміщення молекул $\mathrm{H}_{2} \mathrm{O}$ на $\mathrm{NO}_{3}^{-}-$ групи в оточенні $\mathrm{Ln}^{3+}$ створюють умови до утворення відповідних високосиметричних комплексів. Різні способи їх просторового упакування 3 іншими структурними елементами у процесі кристалізації призводять до виділення із рідкої фази аніонних координаційних сполук певного складу й структури. На процеси комплексоутворення впливають природа центрального атомакомплексоутворювача, розупорядковуюча дія на структуру розчинів наявних однозарядних катіонів (наприклад, $\mathrm{K}^{+}$), концентрація і характер теплового руху структурних елементів; виявлено значний вплив температурного чинника, необхідність певної енергії активації для таких перетворень, їх стадійність. Встановлені особливості у сукупній поведінці структурних елементів у вивченій системі вказують на те, що протікаючі конкуруючі реакції $є$ сильнодіючим технологіч- ним чинником, який суттєво впливає на зміну активності структурних форм лантаноїдів.

У роботі проведене також термографічне вивчення твердих фаз, що утворюються в системі нітратів неодиму і калію, з метою пояснення закономірностей, які мають місце у досліджуваних процесах синтезу оксидних РЗЕ-вмісних функціональних матеріалів, а також для порівняльної характеристики, що підтверджує індивідуальність одержаних нових координаційних сполук. Наведені відомості поведінки $\mathrm{KNO}_{3}$ основані на літературних даних [19-22]; $\mathrm{Nd}\left(\mathrm{NO}_{3}\right)_{3} \cdot 6 \mathrm{H}_{2} \mathrm{O}$ (рис. 4), $\mathrm{K}_{2}\left[\mathrm{Nd}\left(\mathrm{NO}_{3}\right)_{5}\left(\mathrm{H}_{2} \mathrm{O}\right)_{2}\right], \mathrm{K}_{3}\left[\mathrm{Nd}_{2}\left(\mathrm{NO}_{3}\right)_{9} \mathrm{H}_{2} \mathrm{O}\right] \cdot \mathrm{H}_{2} \mathrm{O}$ - на даних власних досліджень (рис. 5, табл. 2, 3).

3 нагріванням при $129{ }^{\circ} \mathrm{C}$ відбувається перебудова кристалічної структури нітрату калію. Низькотемпературна форма II- $\mathrm{KNO}_{3}$ зазнає поступове перетворення у розупорядковану форму $\mathrm{I}_{\mathrm{KNO}} \mathrm{i}_{3}$ відноситься до фазових переходів першого роду $\lambda$ - типу, що за твердженням авторів [19] розтягується в інтервал у десятки градусів. Водночас нітрат-іони змінюють як свою орієнтацію, так і відносне положення вздовж осі C; розупорядкування, найвірогідніше, відбувається в результаті гвинтоподібного руху.

Термічне розкладання нітрату калію відбувається вище його температури плавлення $\left(334,5{ }^{\circ} \mathrm{C}\right)$ [20] i починається $>400{ }^{\circ} \mathrm{C}$ [21] за схемою: $\mathrm{NO}_{3}^{-} \leftrightarrow \mathrm{NO}_{2}^{-}+1 / 2 \mathrm{O}_{2}$.

У статті Мелчера [22] в інтервалі температур 500-600 ${ }^{\circ} \mathrm{C}$ відмічене незначне розкладання $\mathrm{KNO}_{3} 3$ утворенням нітритів до $10 \%$. Під час нагрівання нітрату калію вище $700{ }^{\circ} \mathrm{C}$ - утворюється $\mathrm{K}_{2} \mathrm{O}$ і одночасне виділення азоту та кисню [21]. Обидві реакції розкладання являються ендотермічними.

Термічне розкладання $\mathrm{Nd}\left(\mathrm{NO}_{3}\right)_{3} \cdot 6 \mathrm{H}_{2} \mathrm{O}$ носить складний характер (рис. 4).

Одержані результати узгоджуються 3 відомостями наведеними у роботі Нісена [23]. При $74{ }^{\circ} \mathrm{C}$ $\mathrm{Nd}\left(\mathrm{NO}_{3}\right)_{3} \cdot 6 \mathrm{H}_{2} \mathrm{O}$ плавиться в кристалізаційній воді (початок плавлення $68^{\circ} \mathrm{C}$ ). В інтервалі температур 74-224 ${ }^{\circ} \mathrm{C}$ перетворення відбуваються у рідкій в'язкій метастабільній фазі, внаслідок нестійкості його кристалогідратних форм. Піки на кривих ДТА, ДТГ $з$ екстремумами $154,224{ }^{\circ} \mathrm{C}$ відповідають ендоефектам, що накладаються, i пов'язані з обезвожуванням зразка по схемі:

$$
\mathrm{Nd}\left(\mathrm{NO}_{3}\right)_{3} \cdot 6 \mathrm{H}_{2} \mathrm{O} \stackrel{68-122^{\circ} \mathrm{C}}{\longrightarrow} \mathrm{Nd}\left(\mathrm{NO}_{3}\right)_{3} \cdot 5,5 \mathrm{H}_{2} \mathrm{O} \stackrel{122-210^{\circ} \mathrm{C}}{\longrightarrow} \mathrm{Nd}\left(\mathrm{NO}_{3}\right)_{3} \cdot 1,5 \mathrm{H}_{2} \mathrm{O} \stackrel{210-277^{\circ} \mathrm{C}}{\longrightarrow} \mathrm{Nd}\left(\mathrm{NO}_{3}\right)_{3}
$$




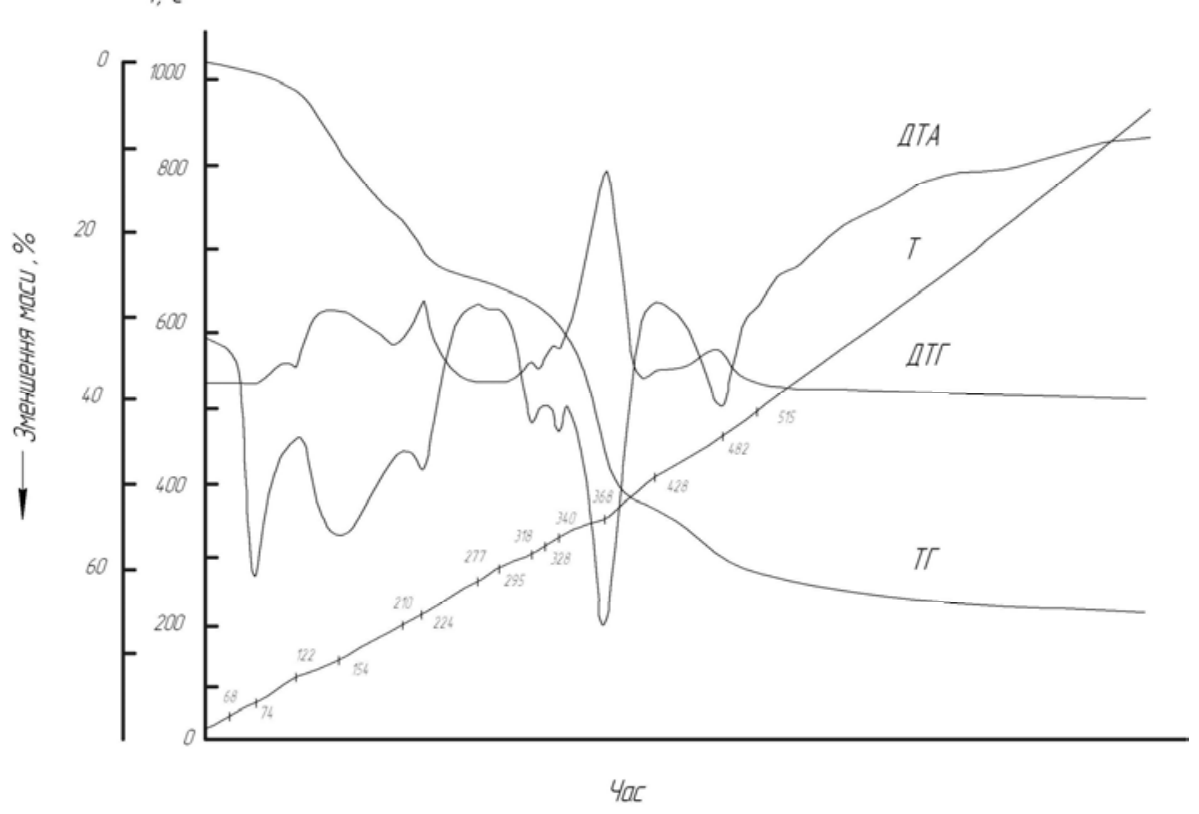

Рис. 4. Дериватограма $\mathrm{Nd}\left(\mathrm{NO}_{3}\right)_{3} \cdot 6 \mathrm{H}_{2} \mathrm{O}$

Безводний нітрат неодиму існує в температурному інтервалі $277-295^{\circ} \mathrm{C}$. На це вказують також домінування зв'язків $\mathrm{Nd}-\mathrm{ONO}_{2}$ в розплаві кристалогідратних форм нітрату неодиму в спектроскопічних дослідженнях [24] та чітка стехіометрія, а також вміст складних оксинітратів, що утворюються на наступних стадіях розкладання.
Факт існування $\mathrm{Nd}\left(\mathrm{NO}_{3}\right)_{3}$ спрощує елементний аналіз досліджуваних зразків та дає можливість проводити аналітичні визначення за сухим залишком.

У роботі Нісена [23] на основі даних хімічного i термографічного аналізів пропонується схема подальшого розкладання $\mathrm{Nd}\left(\mathrm{NO}_{3}\right)_{3}$

$$
\begin{gathered}
4 \mathrm{Nd}\left(\mathrm{NO}_{3}\right)_{3} \stackrel{295-345^{\circ} \mathrm{C}}{\longrightarrow} \mathrm{Nd}_{4} \mathrm{O}\left(\mathrm{NO}_{3}\right)_{10}+2 \mathrm{NO}_{2}+\frac{1}{2} \mathrm{O}_{2}\left(330{ }^{\circ} \mathrm{C}\right), \\
\mathrm{Nd}_{4} \mathrm{O}\left(\mathrm{NO}_{3}\right)_{10} \stackrel{345-395^{\circ} \mathrm{C}}{\longrightarrow} 4 \mathrm{Nd} \mathrm{ONO}_{3}+6 \mathrm{NO}_{2}+1 \frac{1}{2} \mathrm{O}_{2}\left(356,365{ }^{\circ} \mathrm{C}\right), \\
10 \mathrm{NdONO}_{3} \stackrel{395-500^{\circ} \mathrm{C}}{\longrightarrow} \mathrm{Nd}_{10} \mathrm{O}_{13}\left(\mathrm{NO}_{3}\right)_{4}+6 \mathrm{NO}_{2}+1 \frac{1}{2} \mathrm{O}_{2}\left(450{ }^{\circ} \mathrm{C}\right) .
\end{gathered}
$$

За нашими даними $\mathrm{Nd}_{2} \mathrm{O}_{3}$ утворюється за температури вище $515^{\circ} \mathrm{C}$.

Термічні перетворення виявленних у водносольовій системі калієвих координаційних сполук неодиму (представника церієвої підгрупи) та ітербію (представника ітрієвої підгрупи) [25] прослідковані до $1000{ }^{\circ} \mathrm{C}$ і приведені на рисунку 5 .

Значення температур виявлених ефектів, їх характер, природа систематизовані і зведені в таблицях 2, 3. Одержані дані дають змогу проводити ідентифікацію фаз. Встановлена низка особливостей та закономірностей. Робимо їх обгрунтування $з$ позицій конкуруючих процесів.

Виходячи 3 особливостей проведення технологічних процесів одержання оксидних РЗЕвмісних функціональних матеріалів, становлять інтерес межі концентраційних співвідношень компонентів, яким на фазових діаграмах відповідають поля кристалізації вихідних нітратів РЗЕ, координаційних сполук, їх сумішей.

Результати досліджень термічних перетворень нових твердих фаз, виявлених у модельній системі (рис. 5, табл. 2, 3), свідчать про різний характер процесів перетворення сполук РЗЕ церієвої і ітрієвої підгруп, низько- і високотемпературних форм сполук «легких лантаноїдів». Термограми сполук елементів першої підгрупи характеризуються утворенням безводних нітратів. Зі сполук 3 однойменним зовнішньосферним катіоном термостійкіші нітрати з більшим вмістом лантаноїду. 


\section{Дериватограми}
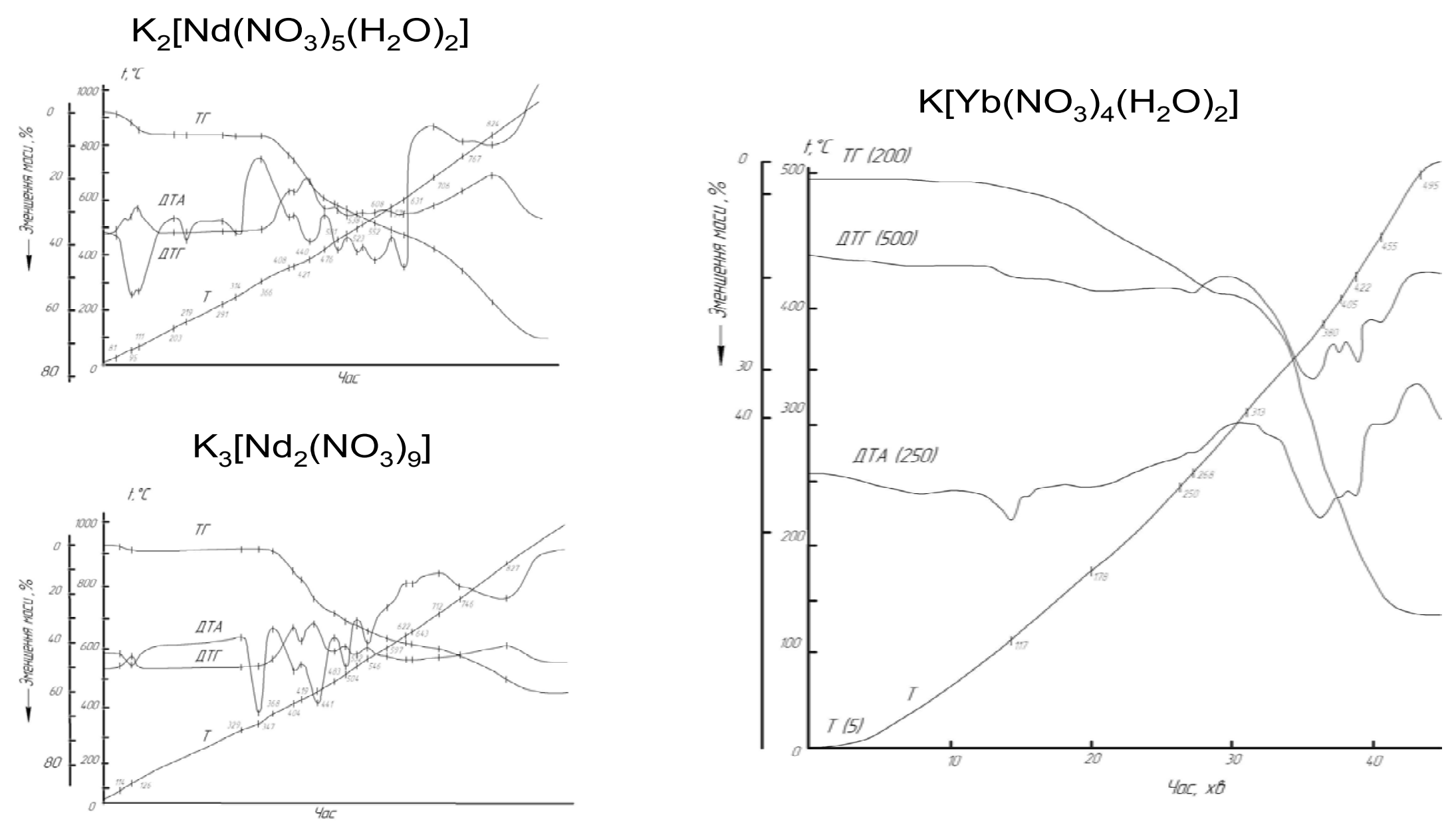

Рис. 5. Дериватограми калієвих координаційних нітратів неодиму та ітербію 
2. Температури перетворень представників груп координаційних нітратів РЗЕ

\begin{tabular}{|c|c|c|c|c|c|c|}
\hline Сполуки & 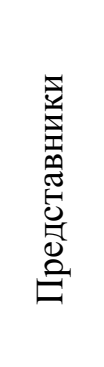 & 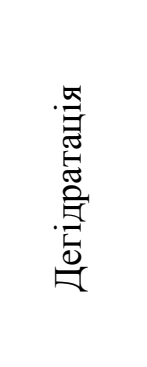 & 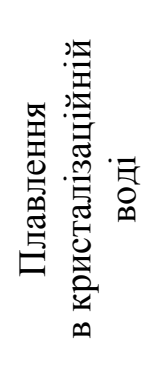 & 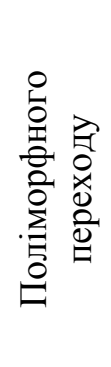 & 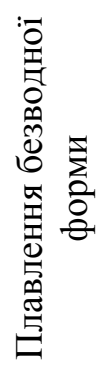 & . \\
\hline $\mathrm{K}_{2}\left[\mathrm{Ln}\left(\mathrm{NO}_{3}\right)_{5}\left(\mathrm{H}_{2} \mathrm{O}\right)_{2}\right]$ & 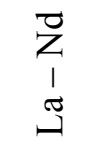 & 95,111 & 95 & 219 & 314 & $\begin{array}{c}\text { церієва підгрупа, } \\
\text { значення для коорд. } \\
\text { сполуки Nd }\end{array}$ \\
\hline $\mathrm{K}_{3}\left[\operatorname{Ln}_{2}\left(\mathrm{NO}_{3}\right)_{9}\right] \cdot \mathrm{H}_{2} \mathrm{O}$ & 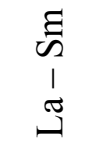 & 126 & - & - & 347 & $\begin{array}{c}\text { церієва підгрупа, } \\
\text { значення для коорд. } \\
\text { сполуки Nd }\end{array}$ \\
\hline $\mathrm{K}\left[\mathrm{Ln}\left(\mathrm{NO}_{3}\right)_{4}\left(\mathrm{H}_{2} \mathrm{O}\right)_{2}\right]$ & $\sum_{i=1}^{1}$ & 138,172 & 138 & - & - & $\begin{array}{c}\text { ітрієва підгрупа, } \\
\text { значення для коорд. } \\
\text { сполуки } \mathrm{Yb}\end{array}$ \\
\hline
\end{tabular}

3. Склад продуктів термолізу (повітря, $980^{\circ} \mathrm{C}$ ) координаційних нітратів РЗЕ, Y $\mathrm{i}$ калію за даними РФА

\begin{tabular}{|c|c|c|}
\hline Сполуки & Представники & Склад продуктів перетворення \\
\hline $\mathrm{K}_{2}\left[\mathrm{Ln}\left(\mathrm{NO}_{3}\right)_{5}\left(\mathrm{H}_{2} \mathrm{O}\right)_{2}\right]$ & $\mathrm{La}-\mathrm{Nd}$ & $\mathrm{KLnO}_{2}, \mathrm{Ln}_{2} \mathrm{O}_{3}$ \\
\hline $\mathrm{K}_{3}\left[\mathrm{Ln}_{2}\left(\mathrm{NO}_{3}\right)_{9}\right] \cdot \mathrm{H}_{2} \mathrm{O}$ & $\mathrm{La}-\mathrm{Sm}$ & $\mathrm{Ln}_{2} \mathrm{O}_{3}$ \\
\hline $\mathrm{K}\left[\mathrm{Ln}\left(\mathrm{NO}_{3}\right)_{4}\left(\mathrm{H}_{2} \mathrm{O}\right)_{2}\right]$ & $\mathrm{Y}, \mathrm{Gd}-\mathrm{Lu}$ & $\mathrm{Ln}_{2} \mathrm{O}_{3}$ \\
\hline
\end{tabular}

Встановлений факт наявності поліморфізму у кристалах сполук складу $\mathrm{K}_{2}\left[\operatorname{Ln}\left(\mathrm{NO}_{3}\right)_{5}\left(\mathrm{H}_{2} \mathrm{O}\right)_{2}\right](\mathrm{Ln}$ $-\mathrm{La}-\mathrm{Nd})$.

Явище можна пояснити тим, що у кристалах виникає розупорядкування, зумовлене доступністю реалізації декількох відмінних орієнтацій іонів $\mathrm{NO}_{3}^{-}$.

Цей вид розупорядкування можливий в силу симетричності як самого плоского $\mathrm{NO}_{3}^{-}$-ліганду, способу координації їх центральним атомом $\left(\mathrm{Ln}^{3+}\right.$-комплексоутворювачем), так i способу упаковки комплексів у просторову будову.

Температурні властивості сполук ітрієвої підгрупи характеризуються відсутністю стійких безводних форм нітратів, низькими значеннями температур плавлення, дегідратацією із розплавленого стану, утворенням $\mathrm{Ln}_{2} \mathrm{O}_{3}\left(980{ }^{\circ} \mathrm{C}\right)$.

Склад продуктів термічного перетворення (порядку $980^{\circ} \mathrm{C}$ ) сполук церієвої підгрупи залежить від складу вихідних нітратів, ступеню летючості оксидів відповідних лужних металів.

У продуктах термолізу сполуки $\mathrm{K}_{2}\left[\operatorname{Ln}\left(\mathrm{NO}_{3}\right)_{5}\left(\mathrm{H}_{2} \mathrm{O}\right)_{2}\right]$, крім оксидів $\mathrm{K}_{2} \mathrm{O}$, містяться також їх диоксолантаноїдати $\mathrm{KLnO}_{2}$.

Аналіз результатів дослідження із власного вивчення модельної системи і системний аналіз відомостей, отриманих із наукових публікацій за тематикою роботи, засвідчує про те, що позитивною особливістю використання вказаних РЗЕвмісних нітратних систем порівняно 3 іншими легкорозчинними системами хлоридів, оксалатів $\epsilon$ те, що конкуруючі іоннообмінні взаємодії призводять до легкого утворення цілого класу аніонних координаційних сполук $\mathrm{Ln}^{3+} 3$ атомами оксигену (донорами електронів) $\mathrm{NO}_{3}{ }^{-}$- груп (лігандів) усього природного ряду рідкісноземельних елементів 3 усіма катіонами лужних металів, а ще до того ж стійких як у розчинах, так і у розплавах.

Це дає можливість здійснювати технологічні перетворення 3 низькими енергетичними затратами (внаслідок малого значення енергії активації процесів комплексоутворення $\operatorname{Ln}^{3+} 3$ планарними малими за розміром $\mathrm{NO}_{3}^{-}$- групами).

Комплексні сполуки легкоплавкі, малоагресивні, елементи церієвої підгрупи - нелеткі.

Це дає змогу працювати за більш низьких температур, розширюється температурний діапазон стійкості комплексних частинок. 


\section{Висновки:}

1. Результати дослідження свідчать, що процеси одержання оксидних РЗЕ-вмісних конструкційних і функціональних матеріалів різного призначення із використанням нітратів елементів різної електронної структури хімічним змішуванням вихідних компонентів під час спільного виділення продуктів із рідкої фази послідовним чи сумісним осадженням з наступним термообробленням відбуваються стадійно через утворення низки проміжних фаз. Їх склад, вміст і поведінка у кожному конкретному випадку потребують попередніх системних емпіричних знань про їх сумісну поведінку у повних концентраційних співвідношеннях у заданому температурному інтервалі.

2. Виявлено відмінності у поведінці структур-

\section{БІБЛІОГРАФІЯ}

1. Аносов В. Я. Основы физико-химического анализа / В. Я. Аносов, М. И. Озерова, Ю. Я. Фиалков. - М. : Наука, 1976. - 503 с.

2. Влияние способа получения на фазовые превращения, структуру и магниторезистивные свойства манганитов $\mathrm{La}_{0,7} \mathrm{Sr}_{0,3} \mathrm{MnO}_{3 y}$ / [Белоус А. Г., Пашкова Е. В., Вьюнов О. И. и др.] // Укр. хим. журн. - 2005. - Т. 71. - №5. - С. 17-23.

3. Белоус А. Г. Сложные оксиды металлов для сверхвысокочастотных и высокопроницаемых диэлектриков. / А. Г. Белоус // Укр. хим. журн. 2008. - T. 74. - №1. - С. 3-21.

4. Гавриленко О. М. Кристалохімічні особливості та властивості $\mathrm{Li}+,\{\mathrm{Na}+, \mathrm{K}+\}$ - заміщених ніобатів лантану і структурою дефектного перовскіту / О. М. Гавриленко, О. В. Пашкова, А. Г. Білоус // Укр. хим. журн. - 2005. - Т.71. - №8. C. 73-77.

5. Гавриленко О. М. Літій провідні матеріали на основі ніобатів і танталатів лантану: синтез, структура, властивості / О. М. Гавриленко // Укр. хим. журн. - 2004. - Т. 70. - №9. - С. 31-34.

6. Горощенко Я. Г. Физико-химический анализ гомогенных и гетерогенных систем / Я. Г. Горощенко. - К. : Наукова думка, 1978. - 490 с.

7. Использование особенностей температурных превращений координационных нитратов РЗЭ при изготовлении изделий электронной техники. / [Дрючко А. Г., Стороженко Д. А., Бунякина Н. В. и др.] // Науковий вісник КУЕІТУ. Нові технології. - 2004. - №1-2 (4-5). - С. 53-57.

8. Синтез, структура и свойства системы твердых растворов $\mathrm{La}_{0,7} \mathrm{Ca}_{0,3-\mathrm{x}} \mathrm{Na}_{\mathrm{x}} \mathrm{MnO}_{3}$ / [Дурилин Д. А., Янчевский О. 3., Товстолыткин А. И. и др.] // Укр. хим. журн. - 2004. - Т. 70. - №9. - С. 34-37.

9. Кобилянська С.Д. Синтез нанорозмірних них компонентів у системах лантаноїдів церієвої та ітрієвої підгруп, у їх характері взаємодії, стадійності, особливостях і закономірностях перебігу.

3. Одержані нові знання виступають основою для:

- пошуку способів збільшення активності Lnформ;

- 3'ясування природи послідовних термічних перетворень у нітратних РЗЕ-вмісних багатокомпонентних системах різних агрегатних станів у ході їх термооброблення, умов утворення й існування, властивостей проміжних фаз, впливаючих факторах, можливих способів керування;

- у разі створення сучасних досконалих низькозатратних технологій синтезу функціональних матеріалів різного призначення із відтворювальними властивостями.

систем ( $\mathrm{Li}, \mathrm{La})\{\mathrm{Ti}, \mathrm{Nb}\} \mathrm{O}_{3}$ методом золь-гель / С. Д. Кобилянська, О. М. Гавриленко, Ю. П. Гомза // Укр. хим. журн. - 2010. - Т. 76. - №4. C. $84-88$.

10. Кудренко E. A. Структура прекурсоров сложных оксидов РЗЭ, полученных методом термолиза растворителя / Е.А. Кудренко, И. М. Шмытько, Г. К. Струкова // Физика твердого тела. - 2008. - Т. 50. - Вып. 5. - С. 924-930.

11. Координационные соединения металлов прекурсоры функциональных материалов / [Мазуренко Е. А., Герасемчук А. И., Трунова Е. К. и др. ] // Укр. хим. журн. - 2004. - Т. 70. - №7. C. 32-37.

12. Мuттра Р. Критический взгляд на метаматериалы / Р. Миттра // Радиотехника и электроника. - 2007. - Т. 52. - №9. - С. 1051-1058.

13. Парсонидж Н. Беспорядок в кристаллах / Н. Парсонидж, Л. Стейвли. - М. : Мир, 1982. Ч. $1 .-434 \mathrm{c}$.

14. Пашин С. Ф. Влияние катионного замеще-

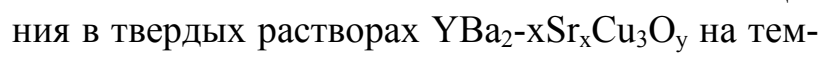
пературу сверхпроводимости / С. Ф. Пашин, Е. В. Антипов, Л. М. Ковба // Сверхпроводимость : физика, химия, техника. - 1990. - Т. 3. №10. - C. 2386-2389.

15. Синтез і властивості композиційних структур на основі сегнетоелектричних та магнітних фаз / [Солопан С. О., В’юнов О. І., Коваленко Л. Л. та ін.] // Укр. хим. журн. - 2006. - Т. 72. - №1. C. 28-31.

16. Термические константы веществ. Таблицы принятых значений. - М. : Наука, 1978. - Вып. Х. Ч. 2. $-442 \mathrm{c}$.

17. Особливості механізмів утворення шаруватих скандатів $\operatorname{SrLn}_{n} \mathrm{Sc}_{n} \mathrm{O}_{3 \mathrm{n}+1}$ із систем сумісно 
закристалізованих нітратів / [Тітов Ю. О., Слободяник М. С., Краєвська Я.А. та ін.] // Укр. хим. журн. - 2010. - Т. 76. - №5. - С 11-16.

18. Туриева Т. И., Глизерман В. И. Спектроскопическое изучение водных растворов нитратов редкоземельных элементов / Т. И. Турцева, В. И. Глизерман // Вестн. Моск. ун-та. Химия. 1973. - T. 14. - №1. - C. 51-54.

19. Шмытько И. М. Инициирующее действие непрерывного нагрева на фазообразование при твердофазном синтезе сложных оксидов редкоземельных элементов / И. М. Шмытько, Е. А. Кудренко, Г. К. Струкова // Письма в ЖТЭФ. - 2007. Т. 86. - Вып. 7. - С. 544-548.

20. Щуров В. Г., Алексеева О. М. Термографические исследования разложения шестиводных нитратов лантаноидов в ряду лантан - самарий /
В. Г. Щуров, О. М. Алексеева. - В кн. : Термический анализ и фазовые равновесия. - Пермь : изд-во Пермск. гос. ун-та. - 1982. - С. 38-45.

21. Carling Robert $W$. Heat capacities of $\mathrm{NaNO}_{3}$ and $\mathrm{KNO}_{3}$ from 350 to $800 \mathrm{~K}$. - Thermochim. Acta / Robert W. Carling. - 1983. - V. 60. - №3 - P. 265-275.

22. Melcher C. L. Nucl. Instr. Methods in Phus. Res / C. L. Melcher. - 2005. - V. 1, A 537. - P. 6-14.

23. Nissen Donald A. Thermophysical properties of the equimolar mixture $\mathrm{NaNO}_{3}-\mathrm{KNO}_{3}$ from 300 to $600{ }^{\circ} \mathrm{C} /$ Donald A. Nissen. - J. Chem. and Eng. Data. - 1982. - V. 27. - №3. - P. 269-273.

24. Ueda K. $3^{\text {rd }}$ Laser Ceramics Symp / K. Ueda. October 8-10, 2007. - Paris, 2007. - P. IO-C-1.

25. Yanagida T., Roh T. et al. Nucl. Instr. Methods in Phus. Res / T. Yanagida, T. Roh et al. - 2007. V. 1, A 579. - P. 23-26. 